\title{
Fikoremediasi Kualitas Lindi TPA Jatibarang Terhadap Efektifitas Lemna minor dan Ipomoea aquatica
}

\author{
Erwin Nofiyanto ${ }^{1}$,Tri Retnaningsih Soeprobowati ${ }^{2}$, dan Munifatul Izzati ${ }^{3}$
}

1Magister Biologi, Fakultas Sains dan Matematika, Universitas Diponegoro; e-mail : nofiyantoerwin@gmail.com 2Sekolah Pascasarjana, Universitas Diponegoro

${ }^{3}$ Departemen Biologi, Fakultas Sains dan Matematika, Universitas Diponegoro

\begin{abstract}
ABSTRAK
TPA Jatibarang adalah satu-satunya tempat pemerosesan akhir sampah di kota Semarang, yang menghasilkan air lindi dalam jumlah yang besar dengan tingkat polutan yang sangat tinggi seperti amonia-nitrogen, logam berat, garam anorganik dan diklorinasi organik sehingga perlu dilakukan remediasi. Tujuan dari penelitian ini untuk mengetahui fikoremediasi kualitas lindi TPA Jatibarang terhadap efektifitas Lemna minor dan Ipomoea aquatica. Sampel kelimpahan fitoplankton diambil dari 4 aeraktor yaitu Kontrol tanpa tanaman, Lemna minor, Ipomoea aquatica, campuran Lemna minor dan Ipomoea aquatica yang diujikan kualitas air lindi (BOD, COD dan TSS) selama 20 hari dengan konsentrasi lindi 100\%. Hasil penelitian menunjukan terdapat fitoplankton yang mampu hidup di lindi yaitu Chlorella sp yang dapat di jadikan fikoremediasi kualitas air lindi. Kelimpahan Chlorella sp paling tinggi terjadi pada perlakuan kontrol tanpa tanaman, dimana cahaya matahari dapat langsung masuk kebadan air sehingga Chlorella sp. mampu melakukan proses fotosintesis secara maksimal sedangkan kelimpahan Chlorella sp. paling rendah pada perlakuan Lemna minor dimana cahaya matahari sulit menembus badan air karena tertutup rapat oleh daun Lemna minor. BOD, COD dan TSS mengalami penurunan paling tinggi pada hari kelima masing-masing 55\%, 55\% dan 60\% pada perlakuan kontrol. Remediasi kualitas air lindi dengan konsentrasi $100 \%$ kurang efektif dalam penurunan bahan organik-anorganik sehingga harus diencerkan terlebih dahulu.
\end{abstract}

Kata kunci: Fitoplankton, Ipomoea aquatica, Lemna minor , dan Lindi

\begin{abstract}
The Jatibarang landfill is the only final waste disposal site in the city of Semarang, which produces large amounts of leacha te with very high levels of pollutants such as ammonia-nitrogen, heavy metals, inorganic salts and chlorinated organics so remediation needs to be done. The purpose of this study was to determine the phycoremediation of the quality of leachate in Jatibarang landfill against the effectiveness of Lemna minor and Ipomoea aquatica. Phytoplankton abundance samples were taken from 4 aeractors namely Control without plants, Lemna minor, Ipomoea aquatica, mixture of Lemna minor and Ipomoea aquatica which tested the quality of leachate (BOD, COD and TSS) for 20 days with 100\% leachate concentration. The results showed that there were phytoplankton which were able to live in leachate, namely Chlorella sp which could be made into phycoremediation of leachate quality. The highest abundance of Chlorella sp occurs in the control treatment without plants, where sunlight can enter the body directly and so Chlorella sp. able to carry out photosynthesis maximally while abundance of Chlorella sp. the lowest at Lemna minor treatment where sunlight is difficult to penetrate the water body because it is tightly closed by Lemna minor leaves. BOD, COD and TSS on the fifth day decreased 55\%, 55\% and 60\% respectively in the control treatment. Remediation of the quality of leachate with a concentration of $100 \%$ is less effective in decreasing inorganic organic matter so it must be diluted first.
\end{abstract}

Keywords: Phytoplankton, Ipomoea aquatica, Lemna minor, and leachate

Citation: Nofiyanto,E., Soeprobowati, T.R., dan Izzati, M. (2019). Fikoremediasi Kualitas Lindi TPA Jatibarang Terhadap Efektifitas Lemna minor dan Ipomoea aquatica . Jurnal Ilmu Lingkungan, 17(1), 107-112, doi:10.14710/jil.17.1.107-112

\section{Pendahuluan}

TPA Jatibarang adalah satu-satunya Tempat Pemerosesan Akhir (TPA) sampah di kota Semarang, yang menghasilkan air lindi dalam jumlah yang besar dengan tingkat polutan yang sangat tinggi, seperti amonia-nitrogen, logam berat, garam anorganik dan diklorinasi organik. Lindi merupakan cairan dengan bau tidak sedap dan warna gelap yang umumnya mengandung bahan organik dan anorganik tinggi (Peng, 2017).

Komposisi kimia dan mikrobiologis dari TPA lindi bersifat komplek dan bervariasi, karena merupakan hasil endapan sisa buangan, hal ini dipengaruhi oleh kondisi lingkungan, cara operasional tempat pembuangan sampah dan proses dekomposisi sampah (El-fadel et al., 2002 ; Kjeldsen et al., 2002). Kandungan organik dan kelembaban 
yang tinggi pada awal proses biodegradasi dapat mempengaruhi kualitas pengolahan lindi (El-fadel et al., 2002).

Peraturan Menteri Lingkungan Hidup dan Kehutanan Republik Indonesia No. 59 tahun 2016 tentang Baku Mutu Lindi bagi Usaha dan/ Atau Kegiatan Tempat Pemerosesan Akhir Sampah untuk kadar paling tinggi pH 6-9, BOD $150 \mathrm{mg} / \mathrm{L}$, COD 300 mg/L, TSS 100 mg/L, dan Kadmium 0,1 mg/L. Pada pengolahan konvensional efluen yang dihasilkan TPA Jatibarang masih jauh dari standar baku mutu yang diizinkan. Kadar logam berat Kadmium (Cd) pada outlet air lindi TPA Jatibarang adalah 0,862 mg/L (Silaban et al., 2017), Nilai BOD $1600 \mathrm{mg} / \mathrm{L}$, COD $4000 \mathrm{mg} / \mathrm{L}$, TSS $522 \mathrm{mg} / \mathrm{L}$ (Rezagama et al. 2016), Nilai COD $4200 \mathrm{mg} / \mathrm{L}$, TSS $814 \mathrm{mg} / \mathrm{L}$ (Christianty, et al. 2017) sehingga perlu pengelolaan lebih lanjut.

Remediasi (pemulihan) kondisi sumber air dan tanah terkontaminasi yang dilakukan secara fisik, kimia dan biologi, secara biologi dinamakan bioremediasi yaitu penggunaan mikroorganisme yang telah dipilih untuk ditumbuhkan pada polutan tertentu sebagai upaya untuk menurunkan kadar polutan (Priadie, 2012). Berdasarkan organisme yang digunakan, maka bioremediasi terdiri dari (mikro) bioremediasi, fikoremediasi, mikoremediasi, dan fitoremediasi. Penelitian ini menggunakan fitoremediasi yaitu pemanfaatan tanaman hijau untuk pembuangan limbah dan pengendalian limbah, terutama untuk limbah berbahaya seperti logam berat (McCutcheon, et al. 2008) dan Fikoremediasi merupakan salah satu proses bioremediasi dengan menggunakan mikroalga (Rao et al., 2011).

Tumbuhan dapat dijadikan penyerap logam berat atau polutan harus mempunyai sifat fitoremediator, indikator tumbuhan fitoremediator ialah dapat tumbuh atau toleran terhadap polutan tinggi (Peer, et al. 2005). Lemna minor sangat efektif untuk pengujian toksisitas dan remediasi karena mempunyai ukuran kecil, pertumbuhan cepat, struktur internal sederhana dan toleran terhadap kondisi lingkungan seperti pH dan Suhu (Kara, et al. 2003). Kangkung air (Ipomoea aquatica) termasuk tumbuhan yang mampu melakukan adaptasi dengan baik pada kondisi lingkungan dengan kisaran toleransi yang luas terhadap berbagai cekaman (Wang, et al. 2008). Air lindi mengandung berbagai nutrien yang dapat dimanfaatkan oleh organisme autotrof. Organisme autotrof seperti mikroalga merupakan bioremediator yang handal (Soeprobowati, et al. 2013). Pertumbuhan Chlorella pyrenoidosa semakin meningkat hingga kepadatan sel 81 dan 105 kali lipat, menurunkan NH4-N, P04(3)$\mathrm{P}$, COD masing-masing 76,1, 75,8 dan 71,6 \% dari 10\% air lindi (Huang, 2002).

Kandungan polutan pada lindi dapat memberikan efek toksik pada organisme, begitu pula organisme mempunyai kemampuan dalam meremediasi polutan, sehingga penelitian ini bertujuan untuk Fikoremediasi kualitas lindi TPA Jatibarang terhadap efektifitas Lemna minor dan Ipomoea aquatica.

\section{Bahan dan Metode \\ 2.1. Koleksi sampel}

Pengambilan sampel air lindi di lakukan di kolam TPA Jatibarang Kota Semarang, Jawa Tengah Indonesia, terletak di Jatibarang Kelurahan Kedungpane Kecamatan Mijen, Satu-satunya TPA yang terdapat di Kota Semarang (dapat di lihat pada Gambar 1). L.minor dan I.aquatica di ambil dari kolam budidaya kemudian di aklimatisasi selama 2 minggu sebelum digunakan dalam penelitian.

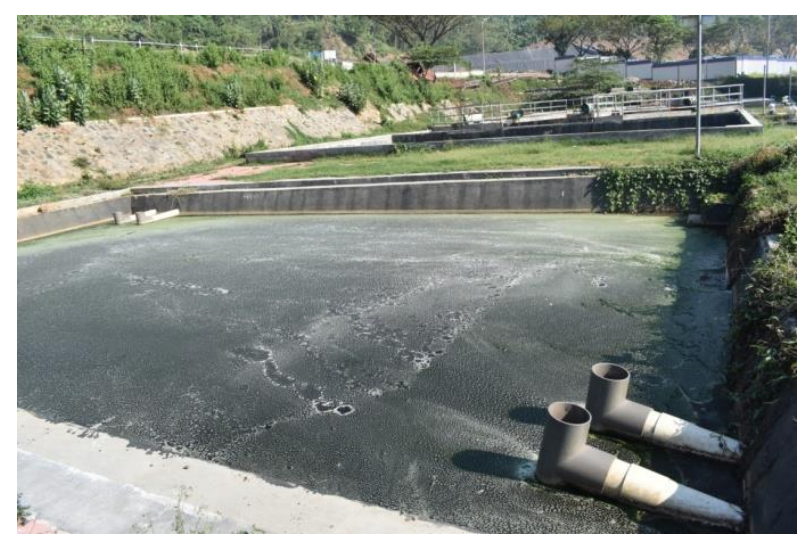

Gambar 1. Kolam pengambilan bahan lindi

\subsection{Metode}

Perlakuan menggunakan desaind RAL terdiri dari 4 percobaan, 3 kali ulangan yaitu L.minor, I.aquatica, campuran L.minor dan I.aquatica dan Kontrol tanpa tanaman. Pengukuran parameter fisika-kimia dan populasi fitoplankton di ukur setiap 5 hari sekali selama 20 hari. Parameter fisika seperti pH dilakukan secara in-situ di setiap percobaan, sedangkan parameter kimia terdiri dari Biochemical Oxygen Demand (BOD), Chemical Oxygen Demand (COD), Total Suspended Solid (TSS) dan Cadmium (Cd) dilakukan secara ex-situ dengan Metode analisis menggunakan spektrofotometri Serapan Atom (AAS).

\section{Analisis sampel}

Sampel air lindi untuk tujuan analisis populasi fitoplankton dikumpulkan menggunakan plankton net (25 $\mu \mathrm{m}$ dalam ukuran mesh) kemudian diawetkan dengan larutan lugol $10 \%$ dan analisis sampel dilakukan secara ex-situ di Laboratorium Ekologi dan Biosistematik Jurusan Biologi Fakultas Sains dan Matematika Universitas Diponegoro, Indonesia. Fitoplankton diidentifikasi secara taksonomi menggunakan mikroskop cahaya, Kelimpahan fitoplankton dihitung berdasarkan rumus (APHA, 2005).

$$
\mathrm{N}=\frac{T}{L} \times \frac{P 1}{P 2} \times \frac{V 1}{V 2} \times \frac{1}{W}
$$

Dimana : N : Kelimpahan plankton (sel L)

$\mathrm{T}$ : Jumlah kotak dalam SRC (1000 $\left.\mathrm{mm}^{2}\right)$

$\mathrm{L}$ : Jumlah kotak dalam satu lapang pandang $\left(\mathrm{mm}^{2}\right)$

P1 : Jumlah plankton yang teramati 
P2 : Jumlah kotak SRC yang diamati

V1 : Volume air dalam botol sampel (ml)

V2 : Volume air dalam kotak SRC

$\mathrm{W}$ : Volume air saluran yang tersaring (L)

\section{Analisis Data}

Air lindi sebelumnya di lakukan pengujian BOD, COD, TSS dan Cd terlebih dahulu untuk mengetahui kandungan bahan organik dan logam berat awal, serta di lakukan pengamatan populasi fitoplankton. Data bahan organik dan logam berat yang diperoleh dibandingkan dengan Peraturan Menteri Lingkungan Hidup dan Kehutanan Republik Indonesia No. 59 tahun 2016 tentang Baku Mutu Lindi bagi Usaha dan/ Atau Kegiatan Tempat Pemerosesan Akhir Sampah.

\section{Hasil dan Pembahasan \\ 5.1. Parameter Karakteristik Awal Lindi}

Karakteristik awal lindi di TPA Jatibarang untuk kandungan BOD, COD, TSS dan Cd dilakukan pengujian karena sesuai penelitian (Rezagama et al. 2016; Christianty, et al. 2017; Silaban et al., 2017) masih jauh di atas baku mutu yang diijinkan, dapat di lihat pada Tabel 1.

Tabel 1. Hasil kandungan BOD, COD, TSS dan Cd di TPA Jatibarang Semarang berdasarkan penelitian terdahulu

\begin{tabular}{|c|c|c|c|c|}
\hline No & Parameter & Konsentrasi & Kadar maksimum (mg L-1) & Sumber \\
\hline \multirow{4}{*}{1} & BOD & 1600 & 150 & \multirow{4}{*}{ Rezagama, et al. 2016} \\
\hline & COD & 4000 & 300 & \\
\hline & TSS & 522 & 100 & \\
\hline & $\mathrm{pH}$ & 8,5 & $6-9$ & \\
\hline \multirow{3}{*}{2} & COD & 4200 & 300 & \multirow{3}{*}{ Christianty, et al. 2017} \\
\hline & TSS & 814 & 100 & \\
\hline & $\mathrm{pH}$ & 8,9 & $6-9$ & \\
\hline \multirow{2}{*}{3} & $\mathrm{Cd}$ & 0,862 & 0,1 & \multirow{2}{*}{ Silaban, et al. 2017} \\
\hline & $\mathrm{pH}$ & 7 & $6-9$ & \\
\hline
\end{tabular}

Hasil kandungan polutan atau logam berat di TPA Jatibarang Semarang berdasarkan penelitian terdahulu didapatkan hasil BOD, COD, TSS dan Cd melebihi kadar maksimum baku mutu lindi yang di ijinkan sehingga penelitian data awal dilakukan sebelum percobaan, terhadap kandungan air lindi di TPA Jatibarang Semarang. Hasil data karakteristik awal lindi TPA Jatibarang dapat dilihat pada Tabel 2.

Tabel 2. Hasil karakteristik awal lindi TPA Jatibarang

\begin{tabular}{clcc}
\hline \hline No & Parameter & Kosentrasi & Baku Mutu (mg/L) \\
\hline 1 & BOD & 1395 & 150 \\
2 & COD & 2717 & 300 \\
3 & TSS & 405 & 100 \\
4 & Cd & $<0,002$ & 0,1 \\
\hline
\end{tabular}

Hasil karakteristik lindi TPA Jatibarang dapat di lihat pada Tabel 2. nilai BOD, COD dan TSS sebesar $1395 \mathrm{mg} / \mathrm{L}, 2717 \mathrm{mg} / \mathrm{L}$ dan $405 \mathrm{mg} / \mathrm{L}$ dimana masih di atas baku mutu, sesuai Peraturan Menteri Lingkungan Hidup dan Kehutanan Republik Indonesia No. 59 tahun 2016 tentang Baku Mutu Lindi bagi Usaha dan/ Atau Kegiatan Tempat Pemerosesan Akhir Sampah, sehingga di lakukan fitoremediasi menggunakan tanaman L.minor dan I.aquatica. Konsentrasi Cd sebesar $<0,002$ nilai ini menunjukan sudah dibawah baku mutu yang diijinkan. TPA Jatibarang yang dijadikan pengambilan sampel merupakan kolam lindi yang masih baru, berumur sekitar 5 tahun. TPA yang telah beroperasi selama lima tahun memiliki BOD 980 $\mathrm{mg} / \mathrm{L}$ dan COD $3552 \mathrm{mg} / \mathrm{L}$ (Salem, et al. 2008). Umur TPA mempengaruhi kualitas Organik Anorganik (Kulikowska, et al. 2008).

\subsection{Analisis L.minor dan I.aquatica sebagai tanaman Fitoremediasi}

Hasil analisis L.minor dan I.aquatica lindi dengan parameter BOD, COD dan TSS pada 4 109 perlakuan yaitu L.minor, I.aquatica, campuran L.minor dan I.aquatica, kontrol tanpa tanaman dibandingkan dengan kualitas air lindi awal (Tabel 2), dapat dilihat pada Tabel 3.

Hasil analisis L.minor dan I.aquatica pada air lindi dapat di lihat pada Tabel 3. Kandungan BOD, COD dan TSS pada lindi masih jauh di atas baku mutu setelah dilakukan perlakuan selama duapuluh hari, hal ini dikarenakan waktu penelitian masih menggunakan lindi dengan konsentrasi 100\% sehingga tidak efektif dalam penurunan kualitas air lindi, hal ini dapat direkomendasikan setiap penelitian lindi harus diencerkan terlebih dahulu.

L.minor dapat menurunkan konsentrasi BOD dan COD pada limbah domestik 76, $54 \%$ pada konsentrasi limbah 50\%, dan $72,44 \%$ pada konsentrasi 20\% (Endro, et al. 2010). Hasil pengamatan yang telah dilakukan penurunan terjadi pada hari kelima, kemudian mengalami kenaikan pada hari kesepuluh dan limabelas walaupun pada hari keduapuluh mengalami penurunan kembali terjadi karena setelah hari kelima pertumbuhan 
tanaman mengalami penurunan dimana proses fisiologi dari tanaman terganggu ditunjukan daun L.minor di air lindi warnanya menguning (klorosis) yang menandakan bahwa L.minor tidak bisa survive karena kandungan polutan lindi yang sangat tinggi. sesuai penelitian Mackenzie et al., (2003) Pertumbuhan dan kandungan klorofil daun L.minor menurun setelah tujuh hari terkena paparan lindi. L.minor juga cukup signifikan penurunan BOD, COD dan TSS Selama 5 hari perlakuan sesuai penelitian Valderrama, et al. (2002). L.minor selama 5 hari mampu tumbuh pada air lindi dan dapat mengurangi bahan organik serta warna hingga 52\%.

Tabel 3. Hasil Analisis L.minor dan I.aquatica pada lindi

\begin{tabular}{ccllll}
\hline \hline Parameter & Hari & Kontrol & L.minor & I. aquatica & $\begin{array}{l}\text { Campuran L.minor } \\
\text { and I.aquatica }\end{array}$ \\
\hline & 5 & $625 \pm 5^{\mathrm{a}}$ & $663 \pm 11.27^{\mathrm{b}}$ & $705 \pm 6.24^{\mathrm{c}}$ & $785 \pm 2.07$ \\
BOD & 10 & $643 \pm 52.05^{\mathrm{a}}$ & $808 \pm 19.00^{\mathrm{b}}$ & $1050 \pm 56.63^{\mathrm{c}}$ & $865 \pm 63.38$ \\
& 15 & $703 \pm 3^{\mathrm{a}}$ & $1105 \pm 73^{\mathrm{c}}$ & $900 \pm 81.85^{\mathrm{b}}$ & $1163 \pm 6.08$ \\
& 20 & $563 \pm 9.54^{\mathrm{a}}$ & $498 \pm 298.5^{\mathrm{a}}$ & $700 \pm 16^{\mathrm{a}^{\mathrm{a}}}$ & $58 \pm 91.59$ \\
& 5 & $1219 \pm 17.69^{\mathrm{a}}$ & $1295 \pm 23.07^{\mathrm{b}}$ & $1386 \pm 3.00^{\mathrm{c}}$ & $1538 \pm 1538$ \\
COD & 10 & $1249 \pm 124.35^{\mathrm{a}}$ & $1569 \pm 7.94^{\mathrm{b}}$ & $2057 \pm 14.93^{\mathrm{c}}$ & $1691 \pm 1691$ \\
& 15 & $1375 \pm 45.9^{\mathrm{a}}$ & $2138 \pm 68.74^{\mathrm{c}}$ & $1793 \pm 3^{\mathrm{b}}$ & $2271 \pm 2271$ \\
& 20 & $1109 \pm 1^{\mathrm{a}}$ & $968 \pm 10.14^{\mathrm{a}}$ & $1359 \pm 244.99 \mathrm{~b}$ & $1140 \pm 1140$ \\
& 5 & $164 \pm 8.72^{\mathrm{a}}$ & $305 \pm 6.08^{\mathrm{b}}$ & $190 \pm 15.62^{\mathrm{a}}$ & $334 \pm 22.52$ \\
& 10 & $107 \pm 11.36^{\mathrm{a}}$ & $110 \pm 13.00^{\mathrm{a}}$ & $201 \pm 26.29 \mathrm{~b}$ & $197 \pm 28.69$ \\
& 15 & $82 \pm 4.58^{\mathrm{a}}$ & $353 \pm 9 \mathrm{c}$ & $244 \pm 11.53^{\mathrm{b}}$ & $357 \pm 6.56$ \\
\end{tabular}

Sumber: PERMENLHK RI No. 59 tahun 2016.

I.aquatica dapat menurunkan kandungan COD, BOD dalam waktu 72 jam pada limbah tekstil (Rane et al., 2016). I.aquatica juga mampu mengurangi berbagai polutan organik dan logam yang sangat beracun (Loan, et al. 2014). Akumulasi logam berat $\mathrm{Pb}$ pada kangkung air yang tumbuh pada aliran air lindi jarak 50 meter lebih besar dibandingkan nilai $\mathrm{Pb}$ dengan jarak 100 meter sebesar $0,182 \mathrm{mg} / \mathrm{L}$ dan $0,125 \mathrm{mg} / \mathrm{L}$, dengan nilai $B A F \quad 1,39$ dan 1 yang termasuk tanaman hiperakumulator (Pertiwi, 2016). Pada hari ke duapuluh COD mengalami penurunan kembali sama dengan BOD, pada masing-masing reaktor sebesar 59\%, 64\%, 50\%, dan 58\%, hal ini dikarenakan pada hari keduapuluh ada bantuan Chlorella sp. dan mikroba yang telah tumbuh pada air lindi (Gambar 2). Terdapat 6 strain isolasi bakteri dapat menurunkan COD sebesar 44\% (Ghosh, et al. 2004).

\subsection{Analisis kelimpahan Fitoplankton}

Populasi fitoplankton di lindi TPA Jatibarang ditemukan spesies Chlorella sp. analisis dilakukan secara taksonomi menggunakan mikroskop cahaya, dengan sampel diambil pada 4 perlakuan, dengan pengambilan setiap 5 hari sekali selama 20 hari, yaitu L.minor, I.aquatica, campuran L.minor dan I.aquatica dan Kontrol tanpa tanaman. Hasil dapat dilihat pada Gambar 2.

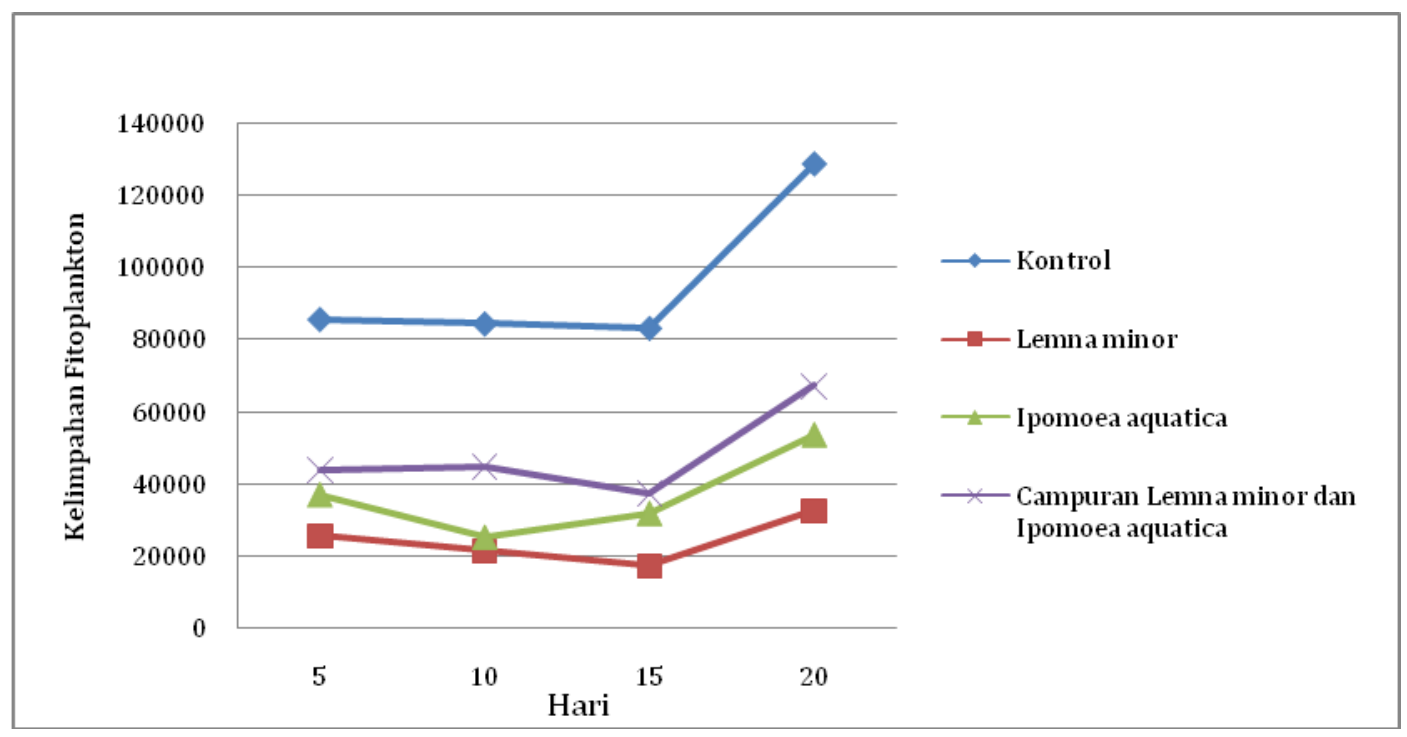

Gambar 2. Analisis kelimpahan fitoplankton pada setiap perlakuan

Hasil kelimpahan fitoplankton dapat di lihat pada Gambar 2. dengan populasi yang ditemukan hanya kelas Chlorophyceae yaitu Chlorella sp. Lindi mengandung berbagai polutan dan logam berat tinggi sehingga hanya organisme tertentu yang dapat bertahan hidup. Chlorella pyrenoidosa memiliki 
kinerja yang sangat baik penghilangan $\mathrm{Cr}, \mathrm{Cu}, \mathrm{Pb}$ dan Cd lebih dari $80 \%$ pada limbah tekstil (Soeprobowati, et al. 2017). Penelitian Huang, (2002) bahwa Pertumbuhan Chlorella pyrenoidosa semakin meningkat hingga kepadatan sel 81 dan 105 kali lipat, menurunkan NH4-N, PO4(3)-P, COD masingmasing 76,1, 75,8 dan 71,6\% dari 10\% air lindi.

Kelimpahan Chlorella sp. menunjukan pada hari pertama hingga hari ke duapuluh mengalami kenaikan. Kelimpahan paling tinggi terjadi pada perlakuan kontrol tanpa tanaman, dimana cahaya matahari dapat langsung masuk kebadan air sehingga Chlorella sp. mampu melakukan proses fotosintesis secara maksimal, oleh karena itu Chlorella sp. lebih banyak dijumpai pada zona fotik (badan air yang masih dapat ditembus sinar matahari). Kelimpahan Chlorella sp. paling rendah pada perlakuan L.minor dimana cahaya matahari sulit menembus badan air karena tertutup rapat oleh daun L.minor. Hasil fotosintesis oleh Chlorella sp. dimanfaatkan sebagai sumber energi oleh organisme pada tingkatan trofik selanjutnya untuk metabolisasi $\mathrm{CO}_{2}$ menjadi senyawa anorganik $\mathrm{CH}_{2} \mathrm{O}$ dengan proses fotosintetik dimana oksigen juga dihasilkan sebagai hasil samping.

Chlorella sp sebelum perlakuan di lakukan analisis kelimpahan di air lindi dimana kelimpahan Chlorella sp rata-rata 17.449 sel L dan setelah perlakuan Fase-lag diamati terjadi pada hari pertama sampai hari kelimabelas hal ini karena jumlah waktu yang diperlukan Chlorella sp untuk adaptasi terhadap air lindi dengan polutan yang tinggi. Air lindi yang digunakan masih $100 \%$ sehingga perlu waktu Chlorella sp dalam beradaptasi. Mikroalga mampu tumbuh dalam larutan yang mengandung hingga $30 \%$ lindi TPA yang di tambahkan limbah kota dengan menghasilkan kosentrasi biomassa 2,8 g/L (Nair \& Nagendra, 2018).

Pertumbuhan Chlorella sp maksimum diamati pada hari ke duapuluh dalam hal ini menunjukan kondisi optimal untuk fikoremediasi. Kultur mikroalga di TPA laogang, shanghai cina dapat menurunkan $90 \%$ total nitrogen dari 10\% lindi (Zhao et al., 2014). Penurunan BOD, COD dan TSS paling tinggi hari ke duapuluh dengan penurunan masingmasing 84\%, 84\% dan 88\% terjadi pada perlakuan L.minor (lihat pada Tabel 2) hal tersebut sesuai penelitian Valderrama, et al. (2002) C. vulgaris digabungkan L.minuscula tumbuh dari 5105 menjadi 2106 sel L pada limbah industry dengan pengurangan ammonium $71,6 \%$, Fosfor $28 \%$ dan COD $61 \%$ yang menunjukan kelayakan penggabungan mikroalga dan macrophytes dalam bioremediasi. Diikuti perlakuan kontrol tanpa tanaman pada hari kelima dengan penurunan BOD, COD dan TSS masing-masing 55\%, 55\% dan 60\%. Hal ini disebabkan pada awal pengamatan tumbuhan akar L.minor dan I.aquatica telah tumbuh dan menyebar secara baik karena telah dilakukan aklimitasi walaupun Chlorella sp pada fase-lag. Tumbuhan dapat bertahan dan tumbuh dengan baik ketika dipindahkan setelah melalui proses 111 aklimatisasi (Hazarika, 2003). Konsetrasi BOD, COD dan TSS pada hari terakhir masih menunjukan diatas baku mutu karena menggunakan lindi 100\%, sehingga hasil fotosintesis oleh Fitoplakton berupa oksigen kurang begitu maksimal dimana jumlah oksigen (BOD, COD) lebih tinggi, dibandingkan jumlah oksigen hasil fotosintesis yang dihasilkan oleh fitoplankton.

\section{Kesimpulan}

Remediasi kualitas air lindi dengan konsentrasi $100 \%$ kurang efektif dalam penurunan bahan organik-anorganik sehingga harus diencerkan terlebih dahulu, terdapat fitoplankton yang mampu hidup di lindi yaitu Chlorella sp yang dapat di jadikan fikoremediasi kualitas air lindi. Kelimpahan Chlorella sp paling tinggi terjadi pada perlakuan kontrol tanpa tanaman, dimana cahaya matahari dapat langsung masuk kebadan air sehingga Chlorella sp. mampu melakukan proses fotosintesis secara maksimal sedangkan kelimpahan Chlorella sp. paling rendah pada perlakuan L.minor dimana cahaya matahari sulit menembus badan air karena tertutup rapat oleh daun L.minor.

\section{DAFTAR PUSTAKA}

American Public Health Association (APHA), A. W. W. A., \& Federation, W. P. C. (2005). Standard Methods for Examination of Water and Wastewater. 21st Ed. American Public Health Association, Washington, DC.

Christianty, D. A., Zaman, B., \& Purwono, P. (2017). Utilization Of Seeds Durian (Durio Zibethinus Murr) Powder AS Biopolymer Additional Materials Of Coagulant Alum To Improve The Total Solids Removal Suspended (Tss) And Cod Using Leachate Coagulation-flocculation (Studi Kasus: Tpa Jatibarang, Kota Semaran. Jurnal Teknik Lingkungan, 6(2), 1-10.

El-fadel, M., Bou-zeid, E., Chahine, W., \& Alayli, B. (2002). Temporal variation of leachate quality from presorted and baled municipal solid waste with high organic and moisture content. Waste Management, 22(3), 269-282.

Endro, S., \& Sri, S. (2010). PENGARUH TANAMAN RUMPUT BEBEK (Lemna minor) TERHADAP PENURUNAN BOD DAN COD LIMBAH CAIR DOMESTIK. Jurnal Presipitasi: Media Komunikasi Dan Pengembangan Teknik Lingkungan, 7(1), 42-47.

Ghosh, M., Verma, S. C., Mengoni, A., \& Tripathi, A. K. (2004). Enrichment and identification of bacteria capable of reducing chemical oxygen demand of anaerobically treated molasses spent wash. Journal of Applied Microbiology, 96(6), 1278-1286.

Hazarika, B. N. (2003). Acclimatization of tissue-cultured plants. Current Science, 85(12), 1704-1712.

Huang, L., Lin, L., Chen, Y., Lan, C., \& Qu, L. (2002). Molecular identification of algae and their use in landfill leachate purification. Acta Ecologica Sinica, 22(2), 253-258.

Kjeldsen, P., Barlaz, M. A., Rooker, A. P., Baun, A., Ledin, A., Christensen, T. H., ... Christensen, T. H. (2012). Present and long-term composition of MSW landfill leachate: a review. Critical Reviews in Environmental Science and Technology, 32(4), 297-336. https://doi.org/10.1080/10643380290813462

Kulikowska, D., \& Klimiuk, E. (2008). The effect of landfill 
age on municipal leachate composition. Bioresource Technology, 99(13), 5981-5985.

Loan, N. T., Phuong, N. M., \& Anh, N. T. N. (2014). The role of aquatic plants and microorganisms in domestic wastewater treatment. Environmental Engineering and Management Journal, 13(8), 2031-2038.

Mackenzie, S. M., Waite, S., Metcalfe, D. J., \& Joyce, C. B. (2003). Landfill leachate ecotoxicity experiments using Lemna minor. Water, Air and Soil Pollution: Focus, 3(3), 171-179.

McCutcheon S. C., J. S. E. (2008). Phytoremediation. Ecological Engineering, 2751-2766.

Nair, A. T., \& Nagendra, S. S. (2018). Chlorella Pyrenoidosa Mediated Phycoremediation of Landfill Leachate. In IMPACT OF GLOBAL ATMOSPHERIC CHANGES ON NATURAL RESOURCES. (pp. 65-68).

Peer, W. A., Baxter, I. R., Richards, E. L., Freeman, J. L., \& Murphy, A. S. (2005). Phytoremediation and hyperaccumulator plants. In Molecular Biology of Metal Homeostasis and Detoxification, 299-340.

Peng, Y. (2017). Perspectives on technology for landfill leachate treatment. Arabian Journal of Chemistry, 10, S2567-S2574.

Pertiwi, P. C. (2016). Akumulasi Logam Berat Timbal (Pb) Pada Tanaman Kangkung Air (Ipomea Aquatica) Yang Tumbuh Di Tpa Sampah Batu Layang Pontianak. Jurnal Mahasiswa Teknik Lingkungan UNTAN, 1(1).

Priadie, B. (2012). TEKNIK BIOREMEDIASI SEBAGAI ALTERNATIF DALAM UPAYA. Jurnal Ilmu Lingkungan, 10(1), 38-48.

Rane, N. R., Patil, S. M., Chandanshive, V. V., Kadam, S. K., Khandare, R. V., Jadhav, J. P., \& Govindwar, S. P. (2016). Ipomoea hederifolia rooted soil bed and Ipomoea aquatica rhizofiltration coupled phytoreactors for efficient treatment of textile wastewater. Water Research, 96, 1-11.

Rao, P. H., Kumar, R. R., Raghavan, B. G., Subramanian, V. V, \& Sivasubramanian, V. (2011). Application of phycoremediation technology in the treatment of wastewater from a leather-processing chemical manufacturing facility. Water $S A, 37(1), 7-14$.

Rezagama, A., Hadiwidodo, M., Purwono, P., Ramadhani, N. F., \& Yustika, M. (2016). Penyisihan Limbah Organik Air Lindi TPA Jatibarang Menggunakan KoagulasiFlokulasi Kimia. Jurnal Teknik, 37(2), 78-83.
Salem, Z., Hamouri, K., Djemaa, R., \& Allia, K. (2008). Evaluation of landfill leachate pollution and treatment. Desalination, 220(1-3), 108-114.

Silaban, D. S., Sulistyani, S., \& Rahardjo, M. (2017). Efektivitas Variasi Dosis Ferri Klorida (Fecl3) Sebagai Koagulan Dalam Menurunkan Kadar Kadmium (Cd) Pada Air Lindi Tpa Jatibarang Semarang. Jurnal Kesehatan Masyarakat (e-Journal), 5(1), 438-443.

Sites, [PERMENLHK]. Concerning Leachate Quality Standards for Businesses and/or Activities of Waste Final Prosessing. Republic of Indonesia Minister of Environment and Forestry Regulation Number P.59/Menlhk/ Setjen/ Kum.1/ $7 / 2016$ (2016).

Soeprobowati, T. R., \& Hariyati, R. (2013). Bioaccumulation of $\mathrm{Pb}, \mathrm{Cd}, \mathrm{Cu}$, and $\mathrm{Cr}$ by Porphyridium cruentum (SF Gray) Nägeli. International Journal of Marine Science, 3.

Soeprobowati, T. R., \& Hariyati, R. (2017). The phycoremediation of textile wastewater discharge by Chlorella pyrenoidosa H . Chick , Arthrospira platensis Gomont, and Chaetoceros. Aquaculture, Aquarium, Conservation \& Legislation, 10(3), 640651.

Valderrama, L. T., Del Campo, C. M., Rodriguez, C. M., DeBashan, L. E., \& Bashan, Y. (2002). Treatment of recalcitrant wastewater from ethanol and citric acid production using the microalga Chlorella vulgaris and the macrophyte Lemna minuscula. Water Research, 36(17), 4185-4192.

Wang, K. S., Huang, L. C., Lee, H. S., Chen, P. Y., \& Chang, S. H. (2008). Phytoextraction of cadmium by Ipomoea aquatica (water spinach) in hydroponic solution: effects of cadmium speciation. Chemosphere, 72(4), 666-672.

YEŞIM KARA, DAVUT BAŞARAN, IZZZET KARA, A. Z. A. H. G. (2003). Bioaccumulation of Nickel by Aquatic Macrophyta Lemna minor (Duckweed ). International Journal of Agriculture \& Biology, 5(3), 281-283.

Zhao, X., Zhou, Y., Huang, S., Qiu, D., Schideman, L., Chai, X., \& Zhao, Y. (2014). Characterization of microalgaebacteria consortium cultured in landfill leachate for carbon fixation and lipid production. Bioresource Technology, 156, 322-328. 